\title{
PENGARUH ECONOMIC VALUE ADDED (EVA) DAN KOMPONEN- KOMPONEN EVA TERHADAP IMBAL HASIL SAHAM PADA INDUSTRI BARANG KONSUMSI DI BURSA EFEK INDONESIA
}

\author{
Yusbardini \\ Fakultas Ekonomi, Universitas Tarumanagara \\ Email: yusbardini@fe.untar.ac.id
}

\begin{abstract}
This study aims to prove whether EVA components can explain stock returns both partially and simultaneously. Research was conducted on consumer goods industry at Indonesia Stock Exchanges in Jakarta and through the internet to retrieve research data. The time period of research object taken is from the 2005-2009 financial year. Sampling method is purposive sampling. This study uses regression that is tested with a statistical approach, namely overall (f-Statistics), partial test (t-Statistic) and Beta or Standardized Coefficient testing. The results of the analysis of the EVA components, namely Cost of Capital (CC), After Tax Interest (ATI), Accrual (ACC), Accounting Adjudication (AccAdj) and Cash Flow Operation (CFO) together (multivariate) can be significant, while partially, only ACC significantly affects stock returns. EVA partially does not affect stock returns.
\end{abstract}

Keywords: EVA, stock returns, EVA components, Cost of Capital, After Tax Interest, Accounting Adjustment

\begin{abstract}
ABSTRAK
Penelitian ini bertujuan untuk membuktikan apakah komponen-komponen EVA dapat menjelaskan imbal hasil saham baik secara parsial maupun simultan.Penelitian dilakukan pada industri barang konsumsi di Bursa Effek Indonesia di Jakarta dan melalui internet untuk mengambil data penelitian.Kurun waktu dari obyek penelitian yang diambil adalah tahun buku 2005-2009. Penarikan sampel bersifat purposif sampling.Penelitian ini menggunakan regresi yang diuji dengan pendekatan statistic yaitu keseluruhan (fStatistic), uji parsial (t-Statistic) dan pengujian Beta atau Standardized Coefficient. Hasil analisis terhadap komponen EVA yaitu Capital Carge ( CC), After Tax Interest (ATI), Accrual (ACC), Accounting Adjusment (AccAdj) dan Arus Cash Operasi (CFO) secara bersama (multivariate) dapat signifikan Sedangkan secara parsial hanya ACC yang signifikan mempengaruhi imbal hasil saham. EVA secara parsial tidak berpengaruh terhadap imbal hasil saham.
\end{abstract}

Kata kunci: EVA, imbal hasil saham, komponen EVA

\section{PENDAHULUAN}

\section{Latar Belakang}

Dalam era globalisasi saat ini perusahaan di tuntut untuk lebih meningkatkan efisiensi dan efektifitas kegiatan usahanya untuk menghadapi persaingan usaha yang semakin ketat. Tujuan perusahaan hanya untuk menghasilkan laba yang sebesar besarnya sudah kurang relavan lagi di masa sekarang karena tanggung jawab perusahaan tidak hanya kepada pemilik saja. Tanggung jawab kepada seluruh stakeholder menjadi sangat penting sehingga hal ini menuntut perusahaan untuk menimbang semua strategi yang diambil dan dampaknya pada stakeholder tersebut. Berdasarkan hal ini maka tujuan yang sesuai adalah untuk memaksimalkan nilai suatu perusahaan. Pada kasus perusahaan public nilai perusahaan dikaitkan dengan nilai saham yang beredar di pasar. Penetapan tujuan yang benar akan sangat berpangaruh pada proses pencapaian tujuan dan penetapan kinerja nantinya. Karena kesalahan menentukan tujuan akan berakibat pada kesalahan strategi yang di ambil. Kesalahan pengukuran kinerja akan mengakibatkan kesalahan dalam memberi imbalan atas prestasi yang ada.

Dalam lingkungan bisnis yang kompetitif, perusahaan tidak hanya diharapkan sebagai wealth-creating institution, namun jauh lebih dari itu di harapkan dapat melipat gandakan kekayaannya. Pelipatgandaan kekayaan memerlukan langkah-langkah yang cemerlang. Apabila perusahaan mempunyai tujuan untuk melipatgandakan kekayaan 
pemegang saham, maka ukuran yang digunakan untuk menilai kinerja perusahaan seharusnya mempunyai hubungan langsung dengan return yang diterima oleh pemegang saham. Ukuran kinerja keuangan yang mendasarkan pada laba akuntansi (accounting profit), seperti earning pershare, price earning ratio dan retun onequity, dianggap tidak memadai untuk mengevaluasi efektivitas dan efisiensi perusahaan. Ukuran kinerja keuangan dengan mendasarkan pada laba akuntansi memiliki banyak kelemahan. Kelemahan utama adalah pengukuran ini mengabaikan biaya modal yang seringkali menyulitkan penilaian terhadap perusahaan tersebut apakah terdapat penciptaan nilai atau tidak. Kelemahan lainnya adalah standar akuntansi yang digunakan untuk menghitung laba perusahaan dapat menyebabkan berbagai macam distorsi yang menyebabkan kinerja perusahaan tidak terukur dengan tepat.

Pada saat ini banyak perusahaan menggunakan ukuran kinerja yang lebih menekankan value (value based management).Economic value added yang dipopulerkan dan dipatenkan oleh Steward \& Company, sebuah konsultan manajemen terkemuka adalah merupakan salah satu varian value based management (stewart 1991). Economic value added (EVA) merupakan pengembangan dari empat alternative penilaian saham yaitu earning, aliran kas ,deviden dan kesempatan investasi (investment opportunity)yang kemudian dirumuskan oleh Joel M Stern salah satu pendiri Stern Stewart \& Co menjadi satu faktor yaitu Free Cash Flow (FCF). FCF adalah aliran kas yang berasal dari operasi (laba bersih ditambah non charge ditambah bunga setelah pajak dikurangi dengan kebutuhan atau tambah capital) yang tersedia bagi semua penyedia capital, baik kreditur maupun pemegang saham. Konsep ini kemudian dijadikan sebagai dasar dalam menilai suatu perusahaan.

Economic Value Added (EVA) menghitung economic profit dan bukan accounting profit. Pada dasarnya EVA mengukur nilai tambah dalam suatu periode tertentu. Nilai tambah ini tercipta apabila perusahaan memperoleh keuntungan (profit) diatas cost of capitalperusahaan.Secara matematis EVA dapat dihitung dari laba setelah pajak dikurangi dengan cost of capital tahunan. Kondisi EVA yang positif mencerminkan tingkat pengembalian yang lebih tinggi dari pada biaya modal, sebaliknya EVA negatif menyiratkan adanya penurunan nilai kekayaan. Perusahaan mempunyai kinerja yang semakin bagus bila mampu menghasilkan nilai EVA yang semakin positif.

Beberapa penelitian empiris tentang hubungan EVA dengan harga saham telah banyak dilakukan, seperti penelitian yang dilakukan oleh F O' Byrne (1996) pada pasar modal NYSE diperoleh adanya perubahan nilai pasar saham sebesar $75 \%$ untuk setiap perubahan EVA selama 5 tahun. Sementara itu perubahan pada laba akuntansi (earning) pada periode yang sama hanya5 tahun. Sementara itu perubahan pada laba akuntansi (earning) pada periode yang sama hanya menjelaskan perubahan sebesar $64 \%$.

Lern dan Makhija (1996) melakukan uji sahih atas hubungan MVA/EVA dengan pendapatan saham atau stock return dari 241 perusahaan yang termasuk dalam perangkat pencipta nilai yang setiap tahun diterbitkan oleh Stern Stewart \& Co seperti tersebut diatas yaitu tahun 1987,1988, 1992, dan 1993. Lehn dan Makihja menghitung 6 perangkat (performance measure) yaitu 3 tingkat pengembalian akutansi (ROE,ROI, dan ROS), tingkat pengembalian saham (stock return) serta EVA dan MVA perusahaan tersebut pada setiap tahun di uji. Hasil pengujian menyimpulkan bahwa semuanya menunjukkan hubungan yang positif dengan tingkat pengembalian saham, tetapi walaupun perbedaannya tidak terlalu besar, ternyata hubungan EVA dengan tingkat pengembalian saham memiliki hubungan yang lebih tinggi. Berbeda dengan hasil penelitian Biddle dan kawan kawan (1997) yang meneliti korelasi antara berbagai pengukuran kinerja yang di lakukan terhadap 6.174 perusahaan menunjukkan bahwa $\mathrm{R}^{2}$ dari EBEI adalah sebesar 
12,8 pesen, sedangkan EVA sebesar 6,5 persen, residual income sebesar 7,3 persen dan CFO sebesar 2,3 persen. Selanjutnya penelitian yang dilakukan oleh Garvey dan Milbourn (2000) yang berjudul "EVA versus earnings : Does It Matter Which Is More Highly Correlated with Stock Returns?" penelitian ini lebih menekankan pada situasi yang seperti apa EVA mengalahkan earnings dan mengapa demikian. Hasil penelitian menunjukkan bahwa perusahaan perusahaan yang telah mengadopsi EVA memang memiliki EVA yang berkorelasi yang lebih tinggi u-satdengan return, dibandingkan earnings. Penelitian berikutnya adalah penelitian Peixoto (2001) dengan judul "Economic Value Added Applcation to Portuguese Public Companies". Penelitian ini membandingkan hubungan antara EVA dan MVA dengan hubungan antara MVA dan net income atau operating profit. Hasil penelitian menunjukkan bahwa penelitian variable net income adalah satu-satunya variable yang signifikan secara statistic.Penelitian Fernandez (2001) juga menjadi dasar penelitian ini, yang berjudul "EVA,Economic Profit and Cash Value Added do not measure shareholder value creation". Penelitian ini mengkorelasikan antara kenaikan Market Value Added ( MVA) tiap tahun terhadap nilai EVA, NOPAT dan WACC tahun yang bersangkutan, yang ternyata kemudian menunjukkan hasil bahwa korelasi antara kenaikan MVA dengan variable NOPAT memiliki nilai yang terbesat dibandingkan variable yang lain. Hasil penelitian menunjukkan bahwa tingkat bunga dengan return memiliki korelasi yang tinggi.

Penelitian ini bertujuan untuk membuktikan apakah komponen-komponen EVA dapat menjelaskan imbal hasil saham baik secara parsial maupun simultan. Atas dasar hasil penelitian Peixoto (2001) dan Kurniady (2003) penelitian ini mengambil judul " Analisis Pengaruh EVA dan Komponen-Komponen EVA Terhadap Imbal Hasil Saham.”

Untuk menguji keakuratan dari pengukuran wealth of stockholders (kemakmuran pemegang saham) adalah dengan melihat seberapa besar pengaruh antara output yang dihasilkan oleh pengukuran tersebut terhadap firm value (nilai perusahaan) yang nantinya berdampak pada imbal hasil saham (stock return). Artinya ada asosiasi dan korelasi yang signifikan antara keduanya sehingga pengukuran tersebut benar-benar mencerminkan nilai perusahaan di mata investor. Komponen EVA yang diuji dalam menjelaskan imbal hasil saham adalah : 1. Capital Charge (CC)2. After tax Interest (ATI)3. Accruals (ACC)4. Cash Flow from Operation (CFO) 5. Accounting Adjusment (AccAdj). Hubungan EVA dan komponen EVA dilihat dari persamaan berikut :

$\mathrm{EVA}=\mathrm{CFO}+$ Accrual+ATInt - CapChg+AcctAdj

$\frac{\overline{\text { Net Income }(N I)}}{\text { NOPAT }}$
$\frac{\text { Residual Income }(R I)}{\text { Economic Value Added (EVA) }}$

\section{Hipotesis}

H1: Capital Charge (CC) berpengaruh terhadap imbal hasil saham

$\mathrm{H} 2$ : After tax Interest (ATI) berpengaruh terhadap imbal hasil saham

$\mathrm{H} 3$ :Accruals $(A C C)$ berpengaruh terhadap imbal hasil saham

H4: Cash Flow from Operation (CFO) berpengaruh terhadap imbal hasil saham

H5: Accounting Adjusment (AccAdj) berpengaruh terhadap imbal hasil saham

H6 :CFO, Accrual, ATIn, CapCharge, dan AccAdj secara bersama berpengaruh terhadap imbal hasil saham 
KOMPONEN-KOMPONEN EVA TERHADAP IMBAL

HASIL SAHAM PADA INDUSTRI BARANG

KONSUMSI DI BURSA EFEK INDONESIA

H7 : EVA berpengaruh terhadap imbal hasil saham

\section{Rumusan Masalah}

Apakah komponen-komponen EVA dapat menjelaskan imbal hasil saham baik secara parsial maupun simultan.

\section{METODE PENELITIAN}

Populasi dalam penelitian ini adalah perusahaan-perusahaan yang termasuk dalam industri barang konsumsi yang sahamnya diperdagangkan di Bursa Efek Indonesia. Dipilihnya perusahaan-perusahaan dalam industri tersebut sebagai sampel karena merupakan sektor penting di pasar modal Indonesia. Selain memiliki kapitasisasi pasar yang relatif besar serta likuiditas perdagangan yang baik, jenis usaha serta produk emiten pada sektor konsumsi juga telah dikenal baik oleh investor.Kurun waktu dari obyek penelitian yang diambil adalah tahun buku 2005-2009..Sampel diambil berdasarkan purposive sampling. Pengukuran untuk masing-masing variable adalah sebagai berikut :

1. Variabel terikat

Return saham dihitung dengan Market Adjusted Return yaitu return saham tahunan dikurangi dengan return pasar tahunan. Alasan tidak hanya dipengaruhi oleh kinerja masing-masing saham, tetapi juga oleh perubahan harga masing-masing saham secara riil, maka faktor kondisi sebaiknya dihilangkan. Sedangkan dipilihnyareturn tahunan (periode tahun fiskal) karena variable bebas di peroleh secara tahunan.

2. Variabel bebas

CFO, Accrual, ATIn, CapCharge, dan AccAdj, nilai masing-masing variabel bebas dirubah menjadi nilai relatif yaitu dibagi dengan total asset awal tahun karena variabel terikat dalam nilai relatif.

Model Persamaan Regresi :

1) Model persamaan 1

MAR it $=\beta 0+\beta 1 \mathrm{CC}$ it $+\beta 2 \mathrm{ATI}$ it $+\beta 3 \mathrm{ACC}$ it $+\beta 4 \mathrm{ADJ}$ it $+\beta 5 \mathrm{CFO}$ it $+\varepsilon \mathrm{I}$

Dimana :

MAR it $=($ MAR it - MAR it-1)/MAR it-1 $\quad($ MAR=Market Adjusted Return $)$

$\mathrm{CC}$ it $=$ Capital Charge

ATI it $=$ After tax Interest

ACC it = Accrual,

$\mathrm{ADJ}$ it $=$ Accounting Adjusment

$\mathrm{CFO}$ it $=$ Cash Flow from Operation

2) Model persamaan 2:

MAR it $=\beta 0+\beta 1 X$ it $+\varepsilon I$

Dimana : $\mathrm{X}$ it adalah EVA 


\section{HASIL DAN PEMBAHASAN}

Tabel 1.1

(Sumber: hasil olah data)

\begin{tabular}{|l|l|l|l|l|l|l|l|l|l|}
\hline KET & CONS & EVA & CC & ATI & ACC & ADJ & CFO & F-Stat & Adj R \\
\hline Prediksi & & + & - & + & + & + & + & & \\
\hline Coeficient & $-0,800$ & 3,273 & & & & & & & $0,3 \%$ \\
\hline t-stat & $-2,064$ & 1,145 & & & & & & & \\
\hline prob & 0,042 & 0,255 & & & & & & & \\
\hline Coeficient & $-0,536$ & & $-0,258$ & & & & & & $1,1 \%$ \\
\hline t-stat & $-1,462$ & & $-0,025$ & & & & & & \\
\hline prob & 0,147 & & 0,980 & & & & & & \\
\hline Coeficient & $-0,557$ & & & 2,551 & & & & & $-1,1 \%$ \\
\hline t-stat & $-1,473$ & & & 0,079 & & & & & \\
\hline prob & 0,144 & & & 0,937 & & & & & \\
\hline Coeficient & $-0,691$ & & & & 6,523 & & & & $-11,8 \%$ \\
\hline t-stat & $-2,313$ & & & & 3,599 & & & & \\
\hline prob & 0,023 & & & & 0,001 & & & & \\
\hline Coeficient & $-0,462$ & & & & & 4,323 & & & $-0,7 \%$ \\
\hline t-stat & $-1,367$ & & & & & $-0,646$ & & & \\
\hline prob & 0,175 & & & & & 0,520 & & & \\
\hline Coeficient & $-0,370$ & & & & & & 2,192 & & $-0,3 \%$ \\
\hline t-stat & $-0,997$ & & & & & & 0,870 & & \\
\hline prob & 0,322 & & & & & & 0,687 & & \\
\hline Coeficient & 0,956 & & $-12,566$ & $-16,222$ & 8,489 & $-1,574$ & 4,767 & 0,000 & $10 \%$ \\
\hline t-stat & $-2,062$ & & $-1,037$ & $-0,491$ & 3,661 & $-0,231$ & 1,405 & & \\
\hline prob & 0,042 & & 0,303 & 0,625 & 0,000 & 0,818 & 0,164 & & \\
\hline
\end{tabular}

Dari tabel tersebut di atas dapat dijelaskan bahwa jika masing-masing komponen EVA diregresikan secara parsial (uji t) terhadap imbal hasil saham, hanya Accrual (ACC) yang memiliki koefisien positif dan memiliki pengaruh yang signifikan terhadap imbal hasil saham . Sedangkan komponen-komponen EVA lain tidak signifikan mempengaruhi imbal hasil saham.. Jika dilihat dari persamaan EVA maka dapat dikatakan bahwa Accrual merupakan bagian dari net income dan net income atau pendapatan bersih seringkali menjadi acuan bagi investor untuk menilai kinerja perusahaan dan pada penelitian ini terbukti bahwa net income mempengaruhi imbal hasil saham. Sedangkan komponen EVA lainnya seperti ATIn, CapCharge, dan AccAdj tidak signifikan hal ini disebabkan penyesuaian penyesuaian yang dilakukan dalam penghitungan EVA begitu banyak sehingga seringkali menyulitkan penghitungan EVA yang sebenarnya

Namun jika komponen EVA: Acc, CFO,ATIn, CapCharge, dan AccAdj ini diuji secara bersama sama (uji F) akan berpengaruh terhadap imbal hasil saham namun kontribusinya sangat kecil. Adjusted R Square juga sangat kecil yaitu sebesar $10 \%$ sehingga dapat dikatakan bahwa komponen EVA seperti Acc,CFO,ATIn, CapCharge, dan AccAdj tidak akan memberikan makna kepada nilai imbal hasil saham.

Sedangkan variabel EVA memiliki pengaruh yang positif terhadap imbal hasil saham, walaupun secara model pengaruhnya tidak signifikan.Hasil penelitian ini sesuai dengan penelitian Biddle et al, (1997) bahwa untuk beberapa perusahaan EVA mungkin merupakan alat yang effektif untuk pengambilan keputusan internal, pengukuran kinerja dan kompensasi. EVA tidak mendominasi laba (earning) dalam asosiasinya terhadap imbal hasil saham. Selain itu penelitian ini juga mendukung penelitian Hidayat (2003) yang menyatakan bahwa Accrual adalah komponen EVA yang berpengaruh signifikan terhadap imbal hasil saham. 


\section{KESIMPULAN DAN SARAN}

Dari hasil analisis, maka hasil penelitian ini secara umum dapat disimpulkan sebagai berikut :

1. Hasil pengujian hipotesis (6) terhadap komponen EVA yaitu Capital Carge ( CC), After Tax Interest (ATI), Accrual (ACC), Accounting Adjusment (AccAdj) dan Arus Cash Operasi (CFO) secara bersama berpengaruh terhadap imbal hasil saham.

2. Hasil pengujian hipotesis (1,2,3,4,5) komponen EVA ; Capital Carge ( CC), After Tax Interest (ATI), Accrual (ACC), Accounting Adjusment (AccAdj) dan Arus Cash Operasi (CFO) secara parsial menunjukkan bahwa hanya ACC yang secara signifikan mempengaruhi imbal hasil saham,

3. Sedangkan EVA tidak signifikan pengaruhnya terhadap imbal hasil saham

Penelitian mengenai komponen EVA terhadap imbal hasil saham masih belum banyak dilakukan oleh karena itu disarankan untuk dilakukan penelitian kembali dengan subyek yang berbeda dan data yang lebih banyak.

\section{REFERENSI}

Biddle, G.C et al. (1997), Does EVA Beat Earning? Evidence on Assosiation with Stock Return and Value. Journal of Accounting \& Economics 24,301-336

Bursa Efek Indonesia. Laporan Keuangan Emiten. http://www.jsx.co.id/

Gujarati, Damodar.N. (2003), Basic Econometrics, 4 th ed. McGraw-Hill, New York.

Hidayat, Taufik. (2006), Perbandingan Pengaruh EVA Dan Pengukuran Kinerja Lainnya Terhadap Imbal Hasil Saham Di Indonesia, Jurnal Akuntansi dan Keuangan Indonesia, Januari-Juni

Iqbal,Mohamad (2004). Analisis Analisa Pengaruh EVA,ROA,ROE dan EPS terhadap Harga Saham dan MVA. Tesis Pasca Sarjana Ilmu Ekonomi Fakultas Ekonomi Universitas Indonesia.

Kurniady,Adi (2003). Analisis Information Content dari Economic Value Added (EVA),Operating Income, dan Net Income terhadap Equity Market Value (EMV) dan Market Value Added (MVA). Tesis pada Fakultas Pasca Sarjana Ilmu Manajemen Fakultas Ekonomi Universitas Indonesia.

Lehn, K and Makija, A.K (1997). EVA, Accounting Profit, and CEO Turnover : an empirical examination. Journal of Applied Corporate Finance, vol. 10, No.2.

Roswati. (2007). Relevansi Rasio Keuangan Dengan Harga Saham. Skripsi: FE - UI

Santoso, Singgih. (2000). Buku Latihan SPSS Statistik Parametrik.Jakarta : PT Elex Media Komputindo

Sartono, Agus. (2001). Manajemen Keuangan: Teori dan Aplikasi. Edisi 4. Yogyakarta: BPFE

Sawidji Widoatmodjo. (2005). Car a Sehat Investasi di Pasar Modal.Jakarta : PT Elex Media Komputindo

Setyadharma, Andryan. (2010). Makalah "Uji Asumsi Klasik Dengan SPSS 16.0". Fakultas Ekonomi Universitas Negeri Semarang, Semarang

Siamat, Dahlan. (2004). Manajemen Lembaga Keuangan. Edisi Keempat. Jakarta : Lembaga Penerbit Fakultas Ekonomi Universitas Indonesia . (2005). Manajemen Lembaga Keuangan.Edisi Kelima. Jakarta: Lembaga Penerbit Fakultas Ekonomi Universitas Indonesia 
Stewart, G.Bennett. (1995), Forgot EPS ROE and ROI. EVA is whatdrives stock price. Harvard Bussines Revie, Nov-Des 1995, 20.

Wardhani, Metty. F (2004). Analisa Kandungan informasi pada CFROI, EVA dan Beberapa Pengukuran Kinerja lainnya Terhadap Imbal Hasil Saham. Tesis pada Fakultas Pascasarjana Ilmu Manajemen Fakultas Ekonomi Universitas Indonesia.

Van Home, james C. dan Wachowicz, john M. JR. (2005). Prinsip-Prinsip Manajemen Keuangan. Peneijemah Dewi Fitriasari dan Deny Arnos Kwary. Edisi 12. Jilid 1. Jakarta: Salemba Empat.

Wibowo dan Adorini, Melati. (2006). Analisis Pengaruh Pengumuman Dividen Terhadap Perubahan Harga Saham (Return) Sebelum Dan Sesudah Ex-Dividend Date Di Bursa Efek Jakarta (BEJ).Jurnal Informasi, Perpajakan, Akuntansi dan Keuangan Publik. Vol. 1, No. 2, hal. 73-90

Wicaksono, Ananto Sarono. (2007). Analisis Pengaruh Rasio Keuangan Terhadap Harga Saham Perusahaan Yang Terdaftar di Bursa Efek Indonesia. Universitas Negeri Semarang

Widjajanto, Nugroho. (2001). Sistem Informasi Akuntansi. Jakarta: Erlangga

Yahoo Finance. Historical Price. http://finance.yahoo.com. 